\title{
Bernard Perron \& Mark J.P. Wolf (Eds.): The Video Game Theory Reader 2. New York \& London: Routledge. 2009.
}

\author{
Ole Ertløv Hansen
}

MedieKultur 2010, 49, 198-200

Published by SMID | Society of Media researchers In Denmark | www.smid.dk The online version of this text can be found open access at www.mediekultur.dk

Antologien består af en introduktion fulgt af 16 artikler og et appendiks. Dertil kommer det traditionelle forord, indholdsfortegnelse, litteraturliste og forfatterportrætter. I alt 430 sider med ganske få illustrationer og modeller. Bogen titulerer sig selv en 'reader'. Det er en titel, der forpligter. Her må man forvente, at redaktørerne har kendskab til deres stof og formår at udvælge de rette tekster, således at det faglige udbytte af at læse disse tekster er dækkende for en eller flere, bestemte og/eller skelsættende, adresseringer af fagfeltet. Både The Video Game Theory Reader 1 og 2 snyder lidt på vægten i den henseende, men dog ikke mere, end at man ved at læse på bagsiden af begge eksemplarer hurtigt bliver klar over, at der her er tale om eksplorative artikler, mere end der er tale om etablerede og/eller kanoniserede teoretiske nedslag. Med det in mente vil den her følgende anmeldelse ikke bedømme antologien som en egentlig 'reader', men som det, den er: en antologi af mulige vægtige teoretiske bidrag til forståelsen af computerspil. Anmeldelsen her vil heller ikke forsøge at forholde 2'eren til 1'eren, hvad der ellers let kunne friste. Men nu til det egentlige: Hvad byder denne antologi så på af teoretiske indsigter?

Lad mig starte bagfra. Appendikset er et forsøg på at lave en leksikalsk gennemgang af en række begreber, der har mere eller mindre tilknytning til computerspilsforskningen. Det kan være fint nok med den slags små korte, introducerende leksikonartikler, men da de her er nærmest helt uden referencer, er de stort set ubrugelige. Det er ikke her, man bliver introduceret til et interessant begreb og henvises til, hvor man kan finde uddybende viden om det, så alt i alt er det et temmelig formålsløst appendiks. Af de 16 artikler er de tre mere historiske 
end egentlig teoretiske. En fremstår som afrapportering af et forskningsprojekt, en anden er et normativt indspark i relation til film/spil-spil/film-adaptioner, og en tredje er en diskussion af en række forudsætninger for brugen af syntetiske verdener som eksperimentarium for sociologiske undersøgelser. Frans Mäyräs afsluttende artikel om hans syn på spilforskningens nødvendige interdisciplinære metodik læses langt bedre i hans bog (anmeldt i MedieKultur 46). Nuvel, disse artikler indeholder teoretiske refleksioner, men det er ikke teoretisering, der er deres pointer, så de er på sin vis fejlplacerede i denne 'reader'. Hvordan står det så til med de resterende artikler? Også her starter antologien i et meget lavt gear. Perron og Wolfs indledning opregner en række af de udfordringer, som computerspilsteori står over for eller midt i. Det er ikke nyt stof, men ok, så fik vi da et overblik. Derefter følger et af de efterhånden utallige indslag af semiakademisk karakter, denne gang skrevet af Eric Zimmerman, der forsøger at overføre viden fra Game Design og lægge det til grund for en egentlig teoretisk optik på computerspil. Det normative sigte i artiklen er at danne skole for en ny 'literacy' - et dannelsesideal med udgangspunkt i computerspils "Systems, play and design" (p. 24). Det teoretiske grundlag er langt bedre forklaret i Salen og Zimmermans bog Rules of Play - læs den i stedet. Niveauet hæves ikke i Lars Konzacks efterfølgende artikel om "Philosophical Game Design", der både i sig selv mangler en pointe og på ganske forunderlig vis fuldstændig ignorerer de sidste mange års forskning inden for Philosophy of Computer Games.' Med overskriften "The Video Game Aesthetic" forventer man, at David Myers præcist vil konceptualisere computerspils æstetik. Det sker desværre ikke. Artiklen handler temmelig lidt om æstetik og bygger sin pointe på en tentativ analogi mellem det at spille computerspil og det at læse lyrik: "the video game play experience is perhaps more properly compared to the experience of reading poetic language" (p. 51). Myers får sig argumenteret frem til, at det, der må formodes at være den æstetiske oplevelse, som computerspil tilbyder, er et umiddelbart engagement i den processuelle udfoldes af spillet - en konklusion, som er velkendt, og hvis grundlag præsenteres af Jesper Juul senere i antologien (p. 247).

Som del af den mere antikulturalistiske lejr leverer Andreas Gregersen og Torben Grodal i den næste artikel en undersøgelse af, hvordan interfacesystemer, specielt de nyeste i form af Wii og Eye Toy, kan forstås i en perceptions- og neuropsykologisk optik, og hvorfor de stadig er langt fra at levere den fulde immersion $i$ en virtuel verden. Som de rammende skriver: "players can dance, swordfight, and fish the nights away in the comfort of their living room, but they still get no hugs and kisses" (p. 81). Udfordringen er, at den feedback, på et fuldt kropsligt plan, vi modtager fra den virkelige verden, stadig ikke kan simuleres eller stimuleres. En velargumenteret artikel, der både problematiserer sit teoretiske grundlag og agerer kritisk over for sine undersøgelsesobjekter, men stadig må man pege på, at konklusionen ikke er 'breaking news'. Aki Järvinens efterfølgende forsøg på at systematisere de mulige emotionelle reaktioner, der kan optræde i forbindelse med computerspil, bærer tydeligt præg af at være et koncentrat af forfatterens ph.d.-afhandling, og desværre betyder det, at det nogle steder går lidt stærkt med at argumentere for de teoretiske valg, og disse virker derfor noget tilfældige. Hvorfor er det lige Michael Kubovys ideer om 'pleasure', der 
skal anvendes? Når den åbenlyst har et klart 'body/mind split'-problem (jf. p. 89). Arsenault og Perrons egen artikel udformer en ganske illustrativ model for den proces, det er at spille et computerspil, og de forskellige niveauer, denne kan beskrives på. Igen er der ikke tale om 'breaking news', og deres model holder, som så mange andre, stædigt fast i, at perception er en lineær, nærmest stimulus-respons, funktionalitet. Ganske interessant sætter Sébastian Genvo i sin efterfølgende artikel spot på de delelementer, der indgår i spilprocessen, og får belyst dele af forholdet mellem hvad han kalder 'playable structure', som er spillet, og 'ludic attitude', som er spillerens vilje til at spille. De to sidstnævnte artikler er de første, der præsenterer læseren for egentlig teoribygning. Dette fortsættes dog ikke af Jesper Juul, der i sin artikel går i kødet på paradokset eller modsætningen, der findes mellem spillerens lyst til at spille og spillerens lyst til at vinde. Juul dokumenterer på et empirisk grundlag, at fundamentalet for spil kan formuleres som "a game should be neither too easy nor too hard" (p. 250), som han sætter op som en pendant til Aristoteles' udsagn om, at fortællinger skal have en begyndelse, en midte og en slutning. At det dog ikke kun er spillet selv, der betinger dets oplevelseskvalitet, understreges af Mia Consalvo, der på klassisk Shannon \& Weaver-maner peger på forskellige typer 'støj' i spilprocessen. Hun eksemplificerer disse med såvel teknologiske (lag) som kulturelle former (language \& lingo), der henviser til sprog generelt og til de nærmest kodeagtige forkortelser og neologismer, der anvendes 'in game' af rutinerede og erfarne spillere. Denne artikel er igen ikke teoretisk som sådan, men nærmere deskriptiv.

Sammenfattende må jeg sige, at jeg ikke er synderligt imponeret. Når man kaster sig over en bog, der skulle være en 'theory reader', så er det udmattende at skulle kæmpe sig igennem en række artikler, der slet ikke har dette som omdrejningspunkt. På den måde er antologien, desværre, blot endnu en samling af, hvad der nu kan krybe og gå inden for computerspilsforskningen, som har fået mulighed for at publicere, hvad de nu lige havde på den bærbare. Skal jeg fremhæve to artikler, som på et tidspunkt måske vil kunne få plads i en egentlig 'theory reader', i titlens rette forstand, så må det være Arsenault og Perrons "In the Frame of the Magic Cycle: The Circle(s) of Gameplay" og Genvos "Understanding Digital Playability".

\section{Notes}

1 http://gameconference2009.wordpress.com/about/

Ole Ertløv Hansen Lektor, ph.d. Institut for Kommunikation Aalborg Universitet ertloev@vrmedialab.dk

PS: Jeg var heller ikke vild med 1'eren. 